\title{
Partnerships between the Managements of Cranes (Grus grus) and Kinneret Water Quality Protection in the Hula Valley, Israel
}

\author{
Moshe Gophen \\ Migal Scientific Research Institute, Kiryat Shmone, Israel \\ Email: Gophen@Migal.org.il
}

How to cite this paper: Gophen, M. (2017) Partnerships between the Managements of Cranes (Grus grus) and Kinneret Water Quality Protection in the Hula Valley, Israel. Open Journal of Modern Hydrology, 7, 200-208.

https://doi.org/10.4236/ojmh.2017.72011

Received: March 31, 2017

Accepted: April 27, 2017

Published: April 30, 2017

Copyright $\odot 2017$ by author and Scientific Research Publishing Inc. This work is licensed under the Creative Commons Attribution International License (CC BY 4.0).

http://creativecommons.org/licenses/by/4.0/

\begin{abstract}
The historical habitat of swamps and a lake in the Hula Valley was modified during the early 1950's. The Swamps and the old Hula Lake were drained and the land was converted to an agricultural development. As a result of inappropriate cultivation, it was necessary to once more implement management improvement. It was done within the Hula Project. Part of the Hula Project was a modified usage of $10 \%$ of the area previously used for agriculture for eco-tourism. Independently, thousands of migratory Cranes attracted by peanut crop leftover started wintering in the valley. These bird flocks significantly improved the management objective to ensure prevention of nutrient flux into Lake Kinneret. Consequently, the partnerships between Kinneret water quality protection, nature conservation and agricultural utilization of the peat land is presently operated. Migratory wintered Cranes is a factor of management stability accompanied by costly artificial feeding for bird in a dedicated land block to prevent damage to adjacent crops.
\end{abstract}

\section{Keywords}

Cranes, Hula, Kinneret, Nutrients, Water Quality

\section{Introduction}

The geographical distribution of Common crane (Grus grus) is stretched along the northern parts of Europe and Asia. Breeding populations are found in Scandinavia, Finland Northern Germany and Sweden. Largest flocks of breeding population are known from Russia, where cranes can be found seasonally in Ukraine region throughout the Chukchi Peninsula. Breeding flights extend as far south as Manchuria but mostly in Russia. Common Crane is a long distance migrator. Migration to South last from August to October and the Northern- 
Spring migration is in March through May. The "Western" winter migrators are aimed towards northern Africa, Southern Europe, Portugal, Spain, and France. Intermediate stop locations are existing from Sweden and Germany to China (Caspian Sea included). The "Eastern" winter migrators stay in the river valleys of Sudan, Ethiopia, Tunisia and Eritrea, Turkey, Northern Israel, Iraq and parts of Iran. Wintering regional occupation is also in Northern India, Pakistan, Burma, Vietnam, Thailand and Eastern China. During migration they are characterized by "V" formation flights and typical noisy cry.

A sense of curiosity is motivating and revealing why discussing the involvement of a migratory terrestrial bird in an aquatic ecosystem is essential. The present paper is an attempt aimed at analyzing the role of the Common Crane (Grus grus) in the eco-system of Lake Kinneret and its drainage basin. Common Crane is commonly fed on vegetarian matters like seeds and other plant debris as well as potatoes and insects. This migratory bird used to migrate from Europe in winter, passing over Israel where it made partly practiced landing and wintering (October-March) in the valleys of Hula, Izreel and Hefer, Southern Golan Heights and in North-Western zones of the Israeli Negev desert [1] [2]). The Common Crane is considered terrestrial, mostly populating swampy and moist soil habitats in nature. Additional documentation reports [3], vegetarian food resources consumed by the Crane include plant roots, seeds, and bulbs, as well as Gastropods, Frogs, Insects, Mice and Bird chicks. The Common Crane reproduces (courtship, nesting and offspring care) in northern Europe and Asia during the spring-summer time and migrates southwards from October [3]. The wintering Crane population in Israel during the mid-1980's was about 2500 individuals, mostly in the Valley of Izreel. From the early 1990's vast flocks of Crane populated the Hula Valley during 5 Autumn-Winter months. In the early 1990's a coincidence of two independent events occurred: Peanuts culture in the Peat soil in the Hula valley and the implementation of the Hula Project aimed at hydrological and nutrient removal improvement to protect the Kinneret Water quality. The dense population of Crane in the Hula Valley was initiated in the early 1990's independently with the Hula Project. The Hula project was implemented aimed at improvement of Kinneret water quality. The objective of the present paper is aimed at the presentation of the resulting compatibility of the occurrence of two independent events, Crane populating and the Hula Project.

Until mid 1950's the Hula Valley was covered by Lake Hula and swamps and was not cultivated. Three rivers, Hatzbani, Banyas and Dan, joint together with several other streams, forming the Jordan River which crossed the Hula Valley through re-split three branches. The Jordan River contributes about $70 \%$ of total nutrient inputs to Lake Kinneret, of which over $50 \%$ originate in the Hula Valley region. The natural wetland and old Lake Hula were drained, and converted to agricultural use which served as an income source for regional residents. The drained area was successfully cultivated, agricultural products were economically produced and the nutrient flux into Lake Kinneret did not threaten its water quality. However, as a result of inappropriate irrigation and agricultural me- 
thods desertification processes developed and the agricultural quality of the peat soil quality was damaged, by consolidation and destruction followed by agricultural crops reduction. The result was an increase of threat to water quality in Lake Kinneret from exceeded nutrient fluxes.

A reclamation project (Hula Project; HP) was consequently implemented, aimed at reducing the nutrient fluxes from the Hula peat soil together with economical utilization of the land through a partial shift from agriculture to ecotourism usage. During the 1990's the Cranes used to be very active during day time in feeding and were assembled for night stay underneath Eucaliptus trees in the vicinity. Nevertheless this habitat exposed the birds to predation. Foxes, Wolves, Manguses, and Koyotes chased and preyed the vulnerable birds at night. Consequently the Cranes moved their night stay station to the shallow Agmon Lake. The water refuge gave them full protection from predators whilst raptors (Eagles, Kite etc.) are not relevant (Photos 1-4).

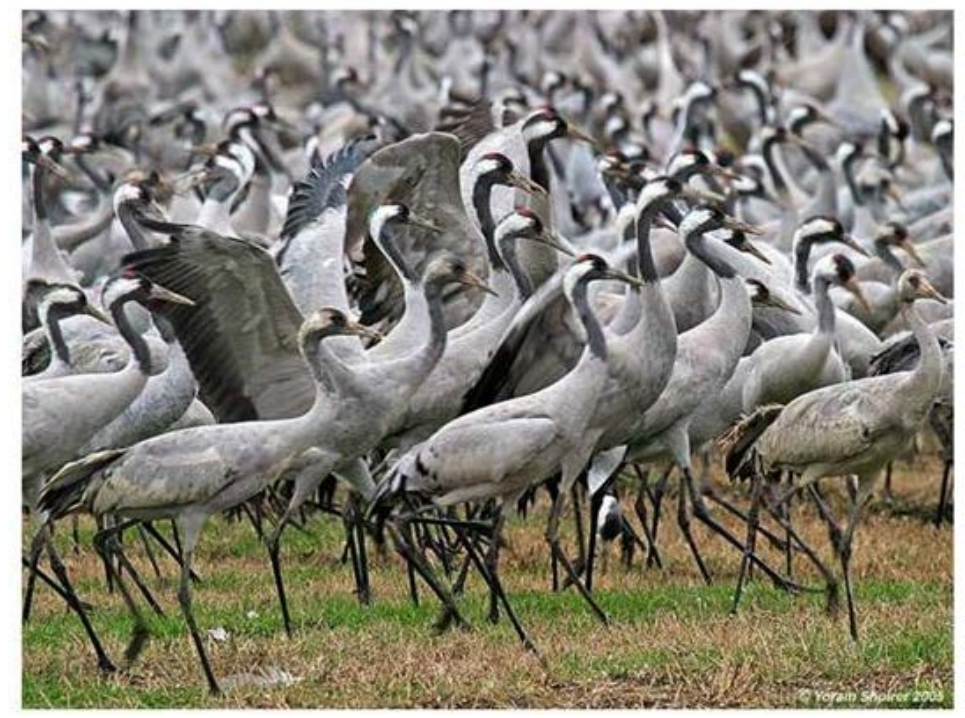

Photo 1. Cranes waiting for corn seeds feeding at the designated field. Photo: JNF (KKL).

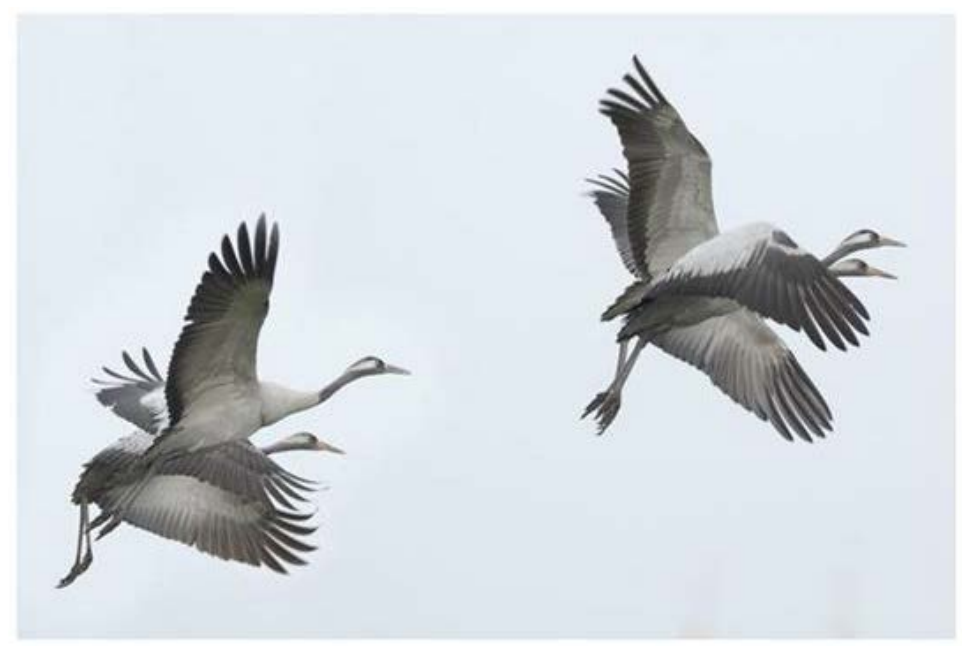

Photo 2. Crane flight over the hula valley. Photo: JNF (KKL). 


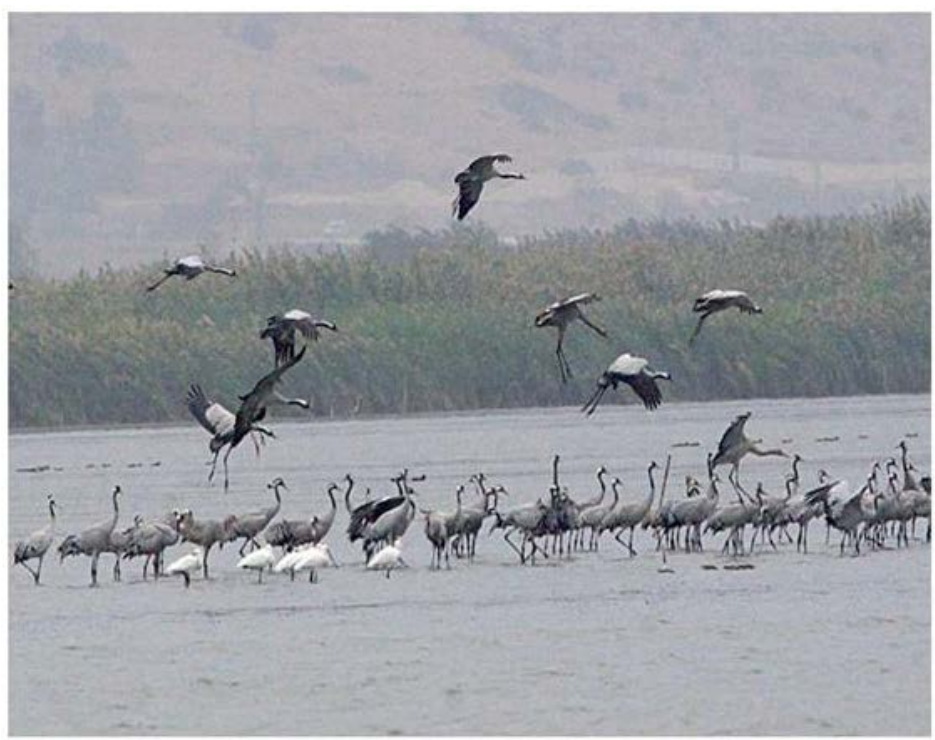

Photo 3. Night crane assemble at the shallow part of Agmon lake. Photo: Y. Naor.

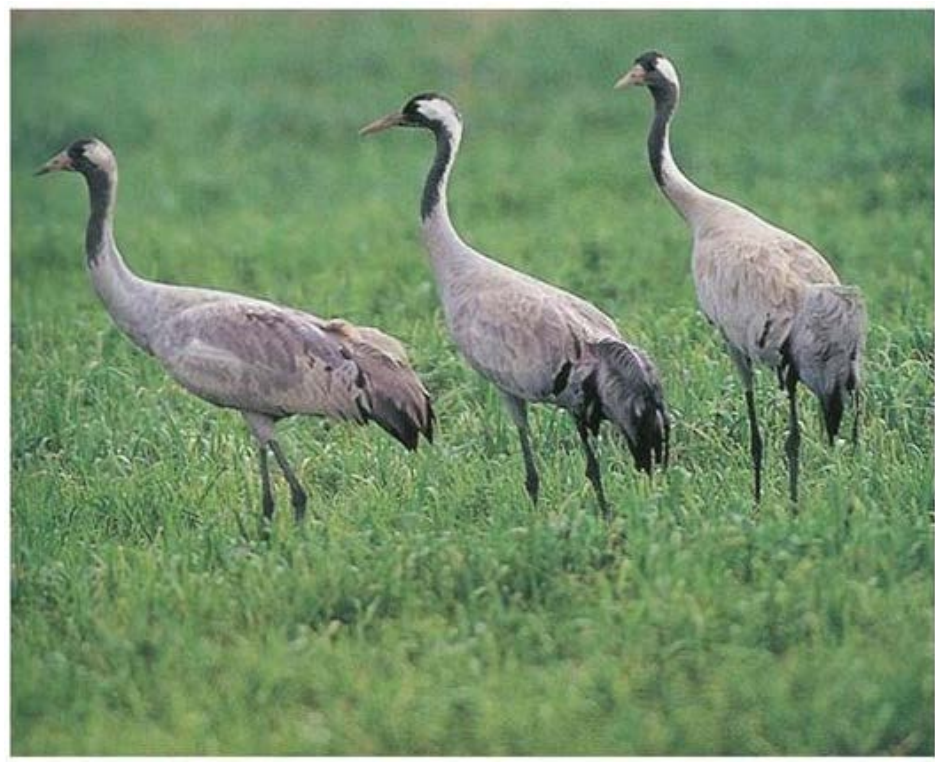

Photo 4. Cranes landed on cultivated field in the hula valley. Photo: JNF (KKL).

\section{Methods}

The material and method background of the Hula Project monitoring and implementation was widely described and documented [4] [5] [6] [7] [8]. Crane monitoring in the Hula Valley, including methods and data, is given in [1] [2] [3] [8] [9] [10]). The Crain feeding program, including Field-Block-Station dedication and corn seeds regime of daily submission, is given in [9] [10]). The annual design of Crane deportation program (start and stop) and prevention of damage to agricultural crops were documented in [9] and [10]. The data of TP concentration in the Jordan river inflow into Lake Kinneret and in the Kinneret Epilimnion was taken from [11]. Total Phosphorus fluctuations in the Agmon outflow and drainage from Peat soil was taken from [6] [8]. 


\section{Results}

In order to prevent agricultural crop Crane damage, the birds are deported from cultivated fields at the beginning of the migration landing (October-November) and later fed by Corn seeds in a special land block dedicated for feeding site (“Crane Hula Restaurant”). The Crane's demands for feeding capacity are presented in Table 1. There was a significant benefit to the landowners from the well-priced recreation bird watching visits which enabled continuity of the outsourced income and hydrological management as an additional partner to ecotourism. Number of Visits is given in Table 2 and the maximum number of counted Cranes per season is shown in Table 3.

Table 1. Number of Feeding Days (per season) and total corn seeds (tons/season) submitted [9].

\begin{tabular}{ccc}
\hline Season & Number of Feeding Days & Tons of Corn seeds \\
\hline $2002 / 03$ & 105 & 250 \\
$2003 / 04$ & 75 & 210 \\
$2004 / 05$ & 60 & 200 \\
$2005 / 06$ & 70 & 240 \\
$2006 / 07$ & 75 & 350 \\
\hline
\end{tabular}

Table 2. Number of visits per Year in the Agmon/Crane site.

\begin{tabular}{lc}
\hline Year & Number of Visits $\left(\times 10^{3}\right)$ \\
\hline 2005 & 200 \\
2006 & 157 \\
2007 & 200 \\
2008 & 250 \\
2009 & 300 \\
2010 & 350 \\
\hline
\end{tabular}

Table 3. The maximum number of wintered migratory Cranes during 1967-2016 per year, $\left(\times 10^{3}\right)$.

\begin{tabular}{lc}
\hline Season & Maximum Number of observed Cranes $\left(\times 10^{3}\right)$ \\
\hline $1996 / 97$ & 22 \\
$1997 / 98$ & 17 \\
$1999 / 20$ & 20 \\
$2001 / 02$ & 27 \\
$2003 / 04$ & 23 \\
$2004 / 05$ & 22 \\
$2005 / 06$ & 33 \\
$2006 / 07$ & 35 \\
$2007 / 08$ & 47 \\
$2008 / 09$ & 50 \\
$2009 / 10$ & 35 \\
$2010 / 11$ & 36 \\
$2011 / 12$ & 37 \\
$2012 / 13$ & 37 \\
$2013 / 14$ & 35 \\
$2014 / 15$ & 37 \\
$2015 / 16$ & 40 \\
\hline
\end{tabular}


Number of visits per year of recreationists are shown in Table 2.

Maximum Number of wintered migratory Cranes stayed in the Hula Vally during 1996/7-2015/16 are shown in Table 3.

\section{Discussion}

Prior to the Hula Swamps and Old Lake drainage $(<1950)$ the major national concern of the state of Israel in the northern areas of the newly established state of Israel was channeled to demography, i.e. population dispersal and agricultural income sources. As a result, the Hula Valley drainage was designed and implemented. Seven years later, when the drainage mission was accomplished, the major concern was transferred to the search for essential utilization of the Hula land soil. Solutions and implementations of agricultural technologies were not easily discovered and plenty of difficulties interrupted efficient utilization. An additional concern was flushed into domestic water supply future design as suspected by the potential flux of nutrients from the degraded Hula peat soil into downstream Lake Kinneret. Precautionary argument of Kinneret water quality threatening by enhanced Eutrophication became relevant shortly later. The obstacle of nutrient flux from the destructed Peat soil into Lake Kinneret, threatening its water quality, became realistic. Those precautions exposed the urgent need for the Hula Project. The performance of the Hula Project included, among other things, the development of a new multipurpose shallow lake, "AgmonHula". The objectives of this new lake were the creation of a sufficient hydrological volume to collect Peat soil drained nutrient-rich water effluents mixed with fresh Jordan River waters. These polluted waters from Lake Agmon-Hula are transferred for irrigation usage outside the Kinneret drainage Basin. AgmonHula shallow lake area is 110 ha and more 390 ha of "Safari Land" in the vicinity were dedicated to natural grass growth which in addition to the lake create a unique landscape unit partly resembling the old swampy natural habitat. The total of 500 ha will not continue to be developed as an agricultural source but modified for Eco-touristic usage. The rational is agricultural development ceasing to be replaced by a shift to another income source for the land owner from priced visitors. Nevertheless, water and aquatic vegetation landscape is insufficient for economical maintenance. In the swampy habitats in the world, the natural element of birds activity is essential. The Crane wintering provided the most attractive solution for this obvious demand as nature tourism (Eco-tourism). The Cranes winter migration to the Hula Valley serve as the most attractive, and the touristic visits were enhanced significantly from about 50,000 during the early 1990's to almost half a million presently. The majority of the visits were claimed as coming to watch the Cranes. Nevertheless, Crane wintering created severe difficulties, including damage of agricultural crop and nutrient (excretions) sources in Lake Agmon-Hula and further to Lake Kinneret: $50 \times 10^{3}$ Cranes excrete 5.24 gP/Ind./day during 170 days (October through Mid March) and produce approximately 44.5 tons of Total Phosphorus, which is mixed with Hula Valley Peat soil and Lake Agmon-Hula waters [4]. Critical indication of 
potential additional $\mathrm{P}$ is aimed at both: Lake Agmon-Hula ecology (Vegetation and Phytoplankton) and P flux through Agmon-Hula outflow and partly through River Jordan discharge [7] [8]. The TP-mass through Lake Agmon-Hula outflow was found to be varied between $0.9-1.6 \mathrm{t} / \mathrm{y}$ and the multi-annual mean range of TP concentration in the Agmon-Hula outlet is $0.01-0.2 \mathrm{ppm}$, and no long-term changes were documented.

Long-term fluctuations of the annual means of Total Phosphorus (TP) concentrations in the Agmon-Hula outflow, Jordan River, and Kinneret Epilimnion [6] [7] [8] [11] indicate the following: Decline in Jordan River from 0.21 to 0.14 ppm (Figure 1); Increase in the Kinneret Epilimnion from 0.015 to $0.021 \mathrm{ppm}$. The seasonal dynamics of TP content in the Agmon-Hula waters (and obviously their outflow) constantly show significant elevation during late summer-Autumn months which is 6 months after Crane northern migration. The TP annual increase of TP late summer-autumn is due to degradation and decomposition of submerged vegetation. Consequently, it is suggested that Cranes do not contribute a significant addition of TP to lake Kinneret and the Epilimnion increase is the result of internal sources. Moreover, positive regressions were indicated between River Jordan discharge and nutrient inflow loads which is $\mathrm{r}^{2}=0.596,(p<$ $0.0001)$ for TP. Independently, the discharges in the Jordan River were declined since the mid-1980's from 15 to $<10 \mathrm{~m}^{3} / \mathrm{s}$ caused by precipitation decline.

The reconstruction of a lost Lake Hula [12] indicated approximately 175 bird species observed in the Hula Valley of which 40 are given as both present and older synonym names. Cranes (Grus grus) are mentioned in this remarkable Avifaunal record only twice [13] [14]. Until the early 1990's Cranes did not visit the Hula Valley except for a few individuals. Since then, the valley is populated annually from November through March by increasing numbers of Cranes. The

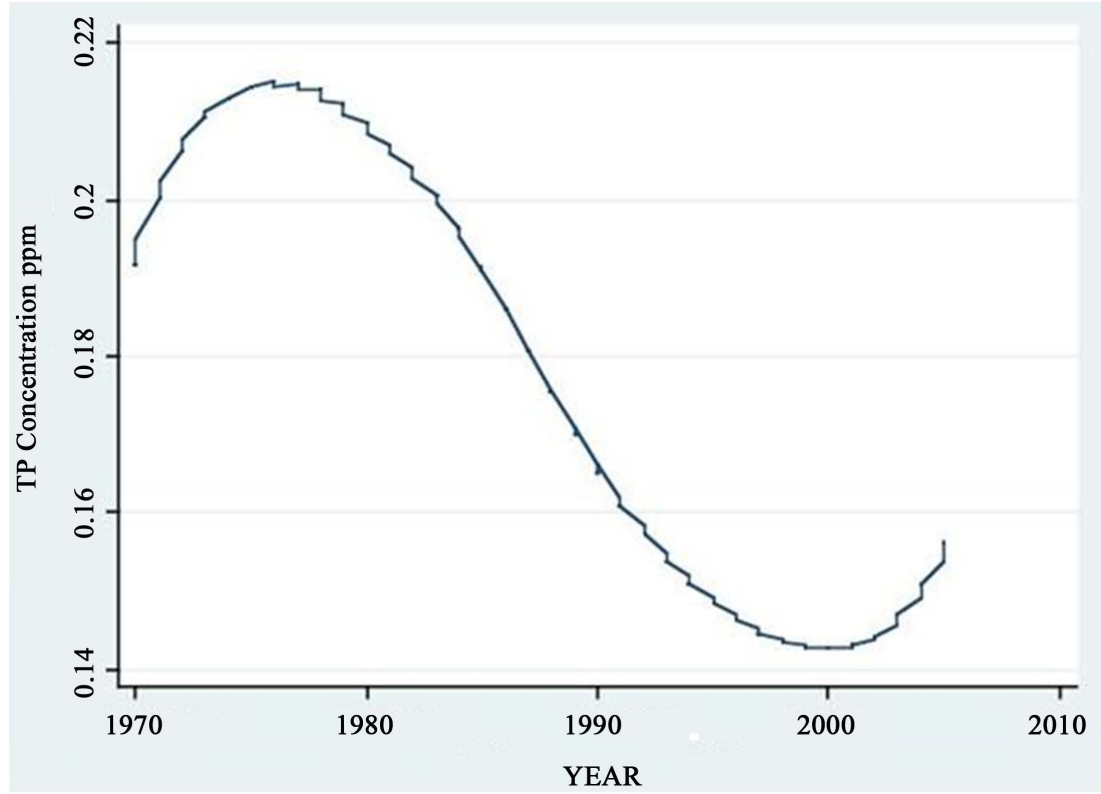

Figure 1. LOWESS (0.8) curve of monthly means of total phosphorus concentration (ppm) in the river Jordan during 1970-2006. 
attractive element which draws wintering Cranes to the Valley is certainly peanut crops. Peanut became an economically successful crop suitable for the heavy-organic-peat soil in the valley routinely cultured. Peanuts are harvested in late Autumn and a lot of seeds are left over exposed on the ground as a result of by incomplete mechanical harvesting technologies. The leftover seeds are preferred by the Cranes which stay over in the valley while migrating from Europe to Africa. One to two months later rainfall starts increasing soil moisture and those seeds are fermented and the Cranes do not like them any more and are looking for another food source. As a result damage is caused to other crops. Cranes are birds protected by International Legislations and shooting them is not permitted. Deportation of Cranes from agricultural field crops during December-March is possible by high volume noise (Cars Alarm) but shooting is absolutely forbidden. A collaborative solution between farmers, nature authorities, water managers, land owners, and regional municipalities was implemented. Money was allocated and for the renting of a 40 ha field block in the valley where Corn seeds are given to the birds twice a day. This achievement initiated benefits for both the landowner farmers by income from bird watchers (priced eco-tourists) and the water managers aimed at protection of the downstream Lake Kinneret waters. Immediately after migratory landing in October the Cranes concentrate on left-over peanuts and about $1-2$ months later they move to the Corn seed feeding station. During the early 1990's the Cranes used to stay overnight underneath terrestrial Eucalyptus trees where they became vulnerable to predators (foxes, wolves, manguses, koyots). Later, the bird flocks changed night stay location to a protected refuge site in the newly created shallow Lake Agmon-Hula. The record of wintering Cranes in the Hula Valley is given in Table 3.

The Crane Project was implemented very successfully. The procedure is for reducing the agricultural damage by Corn seeds feeding in a fixed land site where the Crane birds were accumulated during the day time, leaving this area for night stay in the shallow lake being protected from predators. Bird watchers are visiting and the management of the Hula project removes nutrients from the Kinneret loads. This Crane project represents an efficient partnership of coexisting birds and limnological interests for the prevention of Eutrophication in Lake Kinneret.

\section{Summary and Conclusions}

The Cranes wintering in the Hula Valley unintentionally became a part of a multi-direction program aimed at Kinneret water quality protection. During the long and heavy discussions about the necessity for appropriate management of the Hula Valley land usage and its implementation, the Cranes were never included. The cranes followed the peanut crops and stayed routinely and the cardinal proposed principle of the Hula Project, i.e. eco-tourism, was beneficiary improved. The partnerships between agricultural development, Nature and Kinneret water quality protection are the top successes of the Hula Project. Ecological service of the Hula Valley-Kinneret ecosystem is, therefore, optimized. 
The design of the HP was aimed at consolidation of the conflict between agriculture production, Kinneret water quality protection and nature conservation. Intensive research was initiated, agronomic methods were revised and implemented in a contract with the farmers and the HP program contributed to the stabilization of the Hula valley ecosystem and retarded the desertification process. The tension between farmers, water managers, nature preservation was reduced and collaboration came instead. The outcome of the HP was renewal of an ecosystem, which has become a tourist attraction including enriching the biological diversity with approximately 300 species of birds including $40-50,000$ wintering Cranes annually, and also 40 species of water plants, and 12 fish species. The new ecosystem of shallow Lake Agmon with surrounded Safari habitats ecosystem, became a tourism attraction.

\section{References}

[1] Svensson, L., Grant, P., Mullarney, K. and Zetterstrom, D. (1999) Map-Mapping and Publishing and Hakibbutz Hameuchad Publishers. 408 p.

[2] Alon, D. and Leshem, Y. (2003) Map-Mapping and Publishing and Hakibbutz Hameuchad Publishers. Hebrew Vetrsion, 408 p. (In Hebrew)

[3] Paz, U. (1986) Plant and Animal of the Land of Israel. Vol. 6, Aves. Ministry of Defence and Nature Protection Society Publishers, 486 p. (In Hebrew).

[4] Gophen, M. (2004) Water Utilization in a Semi-Arid Zone, the Hula Valley (Israel): Pollutant Removal, Agriculture and Ecotourism Management. In: Zreiny, F. and Hotzl, H., Eds., Water in the Middle East and in North Africa: Resources, Protection, and Management, Springer-Verlag, Berlin, 207-226.

[5] Gophen, M. (2008) Long Term (1970-2001) Eco-Hydrological Processes in Lake Kinneret and Its Watershed. In: Zereini, H., Ed., Climatic Changes and Water Resources in the Middle East and in North Africa, Springer, Berlin, 373-402.

[6] Gophen, M. (1995-2006) Hula Project Annual Reports. (In Hebrew)

[7] Gophen, M., Bar-Ilan, I., Melman, G. and Yasur, E. (2006) Chapter: Nutrient Dynamics and Hydrology. In: Hula Project, Annual Report, Migal, United States Forestry Service, KKL (JNF), 12-38.

[8] Barnea, I. (2008) Chapter: Hydro-Chemical Monitoring. In: Hula Project Annual Report, Migal, KKL (JNF) and Water Authority, Project No. 4500238147, 11-29. (In Hebrew)

[9] Labinger, Z. and Alon, D. (2006) Chapter: Avifauna Conservation Management in the Hula Valley. In: Gophen, M., Ed., Hula Project Annual Report, 44-74.

[10] Alon, D. and Yom-Tov, Y. (1999-2001) Chapters: Cranes in the Hula Valley. In: Gophen, M., Ed., Hula Project Annual Report, 72-86.

[11] LKDB (1970-2010) Annual Reports, Kinneret Limnological Laboratory Data-Base. (In Hebrew)

[12] Dimentman, C., Bromley, H.J. and Por, F.D. (1992) Lake Hula: Reconstruction of the Fauna and Hydrology of a Lost Lake. The Israeli Academy of Sciences and $\mathrm{Hu}-$ manities, Jerusalem, 170 p. (Addendum in Hebrew 24 p.)

[13] Hardy, E. (1946) Handlist of the Birds of Palestine. Education Office, G.H.O. Middle East Forces, 49 p.

[14] Gorni, E. (1981) Nesting in the Hula Reserve. Summary of the Nesting Season: Spring-Summer, 1980. Nature Reserves Authority, 60 p. (In Hebrew) 
Submit or recommend next manuscript to SCIRP and we will provide best service for you:

Accepting pre-submission inquiries through Email, Facebook, LinkedIn, Twitter, etc. A wide selection of journals (inclusive of 9 subjects, more than 200 journals)

Providing 24-hour high-quality service

User-friendly online submission system

Fair and swift peer-review system

Efficient typesetting and proofreading procedure

Display of the result of downloads and visits, as well as the number of cited articles Maximum dissemination of your research work

Submit your manuscript at: http://papersubmission.scirp.org/

Or contact ojmh@scirp.org 